DOI: https://doi.org/10.46630/bs.2.2019.03

UDK 364.2:316.37

Ивана Илић-Крстић ${ }^{1}$

Универзитет у Нишу

Факултет заштите на раду у Нишу

\title{
СОЦИЈАЛНА БЕЗБЕДНОСТ И ЊЕНЕ ИМПЛИКАЦИЈЕ У СРБИЈИ²
}

\begin{abstract}
Резиме
Потреба за безбедношћу и сигурношћу једна је од примарних потреба поред физиолошких која се јавила код човека. Од првобитне заједнице можемо пратити еволуцију људске потребе за безбедношћу. Јасно је да се безбедност као људска потреба кроз историју мењала. Првобитно поимање безбедности се односило на одсуство физичких претњи и на осећај сигурности по физички интегритет. Касније са друштвеним развојем, безбедност као људска потреба је поред физичке сигурности свој домашај проширила и на забрану дискриминације, односно на поштовање једнакости и социјалне правде као и на поштовање људских права.

У савременој науци егзистира неколико различитих дефиниција и језичких комбинација у тумачењу социјалне безбедности. Концепт социјалне безбедности налази се у средишту интересовања многих друштвених наука. У последњих неколико деценија и на Западу и на Истоку траје развој проучавања социјалне безбедности у знатно ширим оквирима који често захватају готово све области друштвених наука.

У раду се разматрају појмови територијалне и социјалне безбедноси и њихова међузависност и однос, у политичком и економском контексту Србије.

Кључне речи: безбедност, територијана безбедност, социјална безбедност, Србија.
\end{abstract}

\section{УВОДНА РАЗМАТРАЬА}

Временом се увидело да схватање безбедности као заштите територијалног интегритета и суверенитета државе, не може да одговори изазовима савремености, јер су радикално измењени безбедносни услови у којима се нашло глобално друштво, те безбедност појединца, државе и друштва нарушавају и ризици у самој националној држави. Постојање безбедности по мери развоја у савременим условима поставља се на виши ниво и разноликији је. Основним објектом безбедности јављају се: интереси личности - остваривање основних права и слобода, лична безбедност, повећање нивоа квалитета живота, физички, духовни и интелектуални развој; интереси друштва - јачање демократије, досезање мира, одржавање друштвене сагласности, повећање

1 ivana_soc@yahoo.com

2 Припремљено у оквиру пројекта Одрживост идентитета Срба и националних мањина у пограничним општинама источне и југоисточне Србије (179013), који се изводи на Универзитету у Нишу - Машински факултет, а финансира га Министарство просвете, науке и технолошког развоја РС. 
стваралачких активности и духовни препород; интереси државе, уставни поредак, сувереност и територијална целовитост. Остваривање безбедности је повезано са друштвеним односима и законодавним и правним актима (Социологическая энцилопедия, 2003:83). Сходно томе безбедност се може схватити као стање у коме нису угрожени животно важни интереси личности, друштва и државе, односно стање коме не постоје унутрашње и спољашње претње политичког, економског, социјалног, војног, техногеног, еколошког, информативног и др. карактера. Она претпоставља политичку, економску и социјалну стабилност у држави, безусловно остваривање закона и одржавања правног поретка, развој међународне сарадње на основу партнерства (Симић, 2002). У савременим условима говори се о социјалној, еколошкој, економској, здравственој и другим многобројним модалитетима и врстама безбедности.

\section{ПРЕГЛЕД ИСТОРИЈСКОГ РАЗВОЈА СОЦИЈАЛНЕ БЕЗБЕДНОСТИ}

У дефинисању социјалне безбедности треба поћи од савременог схватања безбедности и човекове тежње ка сигурности као универзалног људског усмерења и изградње друштвене праксе која ће у оквиру постојећих културно-етичких вредности створити услове за превазилажење човекове несигурности и ризика у његовом животу. У том смислу, социјална безбедност може се одредити као стање у коме нису угрожени животно важни интереси пре свега појединаца и права која то омогућавају, а дефинисана су у Универзалној декларацији о правима човека Уједињених нација из 1948. године. У члану 22 Декларащије наводи се да свако „као припадник друштва, има право на социјалну безбедност и право да остварује привредна, друштвена и културна права неопходна за своје достојанство и за слободан развој своје личности, уз помоћ државе и међународне сарадње, а у складу с организацијом и средствима сваке државе“ (Универзална декларацији о правима човека, 1948). Остваривање овог права директно је повезано и зависи од остваривања права на рад и слободан избор занимања - запослења, на правичне и задовољавајуће услове рада и на заштиту од незапослености; права на праведну и задовољавајућу накнаду која човеку и његовој породици обезбеђује егзистенцију на нивоу људског достојанства; права човека на разоноду, укључујући ту и право на разумно радно време и плаћени годишњи одмор; права сваког члана људске заједнице на такав стандард живота који обезбеђује његово здравље и благостање његове породице, укључујући храну, одећу и лекарску негу и потребе социјалних служби; права на осигурање у случају останка без посла; права на осигурање за случај болести, инвалидности, удовиштва, старости и других случајева губитка сталних извора прихода услед 
разлога који су ван човекове воље (Универзална декларацији о правима човека, 1948, чл. 23-28).

Пре увођења права на социјалну безбедност, чињени су напори да се оствари неки степен социјалне безбедности, путем законских мера које се односе углавном на сузбијање сиромаштва. На пример, увођењем сиротињског пореза 1601. год. у Енглеској, држава је прикупљала средства за сузбијање сиромаштва, а захваљујући доношењу Сиротињског закона 1834. године почело је оснивање институција за смештај бескућника, болесних и сиромашних. Роберт Овен (Owen) je на Конгресу Свете алијансе 1818. године тражио да се радници ослободе од прекомерне експлоатације. Данијел Ленгранд (Legrand) je 1832. године као задатак европског парламента, одредио доношење закона о смањењу радног времена на 12 сати, забрану ноћног рада за децу и жене, као и увођење старосне границе за децу (10-12 година старости). Године 1890. на Конгресу у Берлину у присуству представника тринаест земаља, донети су међународни закони у области регулисања области рада и права радника која се по том основу остварују. После Првог светског рата 1919. године, основана је међународна организација Друштво народа, која је имала улогу у отклањању катастрофалних последица рата и социјалном збрињавању бројних ратних инвалида, ратне сирочади, као и очување светског мира, развијање међународног социјалног и радног законодавства, забрану дискриминације, трговину женама и децом, као и опијумом, сузбијање болести и очување здравља. Друштво народа је испољило и бројне недостатке и укинуто је 1939. године. Версајским уговором је установљена Међународна организација рада, чије се чланице обавезују да ће обезбедити и развијати правичне услове рада и социјалне безбедности. Године 1827. потписан је први споразум који се односи на старосну пензију, а 1912. године и први споразум о пензијском осигурању. Почетком XX века потписан је и споразум који се односи на права за случај повреде на раду. Касније су донешени прописи о социјалном осигурању, као што су: здравствена заштита, давања за случај болести, материнства, несреће на раду и професионалних обољења, незапослености, старости, породична потпора, инвалидности и осигурања у случају губитка храниоца породице (http:/www.ilo.org/global/ lang-en/index.htm).

Поменимо да се 1966. године у Међународном пакту о економским, социјалним и културним правима човека, поред аспеката социјалне сигурности наводе и безбедност и хигијенски услови рада, подједнаке могућности сваког човека да напредује у свом послу, стално побољшање услова живота, право сваког на социјално обезбеђење укључујући и социјално осигурање (Резолуција ОУН, бр. 2200 А(ХХІ) од 16. 12. 1966).

Безбедност у социјалној сфери осим поштовања поменутих права зависи и од стабилности породице, становања, 
медија и комуникација, локалне заједнице, синдиката, културног идентитета и скупа вредности. (Стратегија националне безбедности Републике Србије, 2009) Социјална безбедност, односно небезбедност обележје је карактеристично за савремени тренутак друштвеног развоја, без обзира на разлике у степену развијености појединачних друштава, те се предузимају одређене делатности усмерене према људским потребама, потребама опстанка и остварењу социјалне безбедности. Првобитно се социјална делатност усмеравала само на обезбеђење потреба опстанка (исхрана, одевање, становање) према члановима заједнице који нису били у могућности да сами себи обезбеде елементарне услове за живот.

За постојање социјалне безбедности од посебног значаја је социјални рад који представља основу социјалне политике једне државе. Усмерен је ка социјално рањивим групама и појединцима у циљу превазилажења социјалних недаћа, „очувања достојанства појединца, развијања његових способности, унапређења интерперсоналних односа, као и решавање социјалних проблема“" (Речник социјалне сигурности, 2006).

Социјални рад се бави практичном делатношћу, радом са појединцима, групама, као и радом у друштвеној заједници и како је још пре скоро пола века написао Вернер Бем (Bohem) „тежи да побољша социјално функционисање индивидуално, појединачно и у групама““ (Bohem, 1958).

\section{СОЦИЈАЛНА БЕЗБЕДНОСТ, СОЦИЈАЛНА СИГУРНОСТ, СОЦИЈАЛНА ЗАШТИТА И СОЦИЈАЛНО ОБЕЗБЕЪЕЊЕ}

Социјална безбедност подразумева стабилност друштвеног положаја, материјалних и културних услова живота, могућност продукције и репродукције живота, услове за оспособљавање за обављање радних и других друштвених улога, стабилност радних услова и радног положаја, спречавање услова који воде ризику погоршања или смањења могућности и услова за живот и рад. Социјалном безбедношћу се може сматрати такво друштвено стање у коме успешно делује један склоп друштвених и законских мера, чији је основни циљ да створе, у корист грађана и његове читаве заједнице, неку врсту гаранције против одређених ризика као што су: болест, материнство, инвалидност, старост, незапосленост, елементарне несреће, повреде на раду и сл.

Степен социјалне безбедности условљен је облицима социјалног осигурања и видовима социјалне заштите у оквиру националне државе. Директно је повезана са класичним облицима социјалног осигурања, социјалне заштите и социјалног обезбеђења читавог становништва у случају болести, инвалидности, старости, смрти и незапослености, везује се за остварење сигурних материјалних услова живота и рада, као и са целовитим, повезаним системом друштвених мера које гарантују одговарајући стандард живота и благостања људи, чији 
је саставни део и подручје социјалног осигурања. Односно, социјална безбедност зависи од скупа друштвених мера и акција које гарантују животне услове људи без ризика. (Симић, 2002) Држава игра значајну улогу у остваривању социјалне безбедности, јер је институција, како тврди Ричард Титмус (Titmuss), која омогућава испуњавање дубоко укорењене жеље у људској природи за помагањем другима. Социјална сигурност и друга социјална давања која омогућава држава, по њему, нису ништа друго до колективни изрази алтруизма друштва и бриге за његове чланове (Bilanović, 2015).

Социјална сигурност може се одредити у ужем и ширем смислу. У ужем обухвата класичне облике социјалног осигурања и социјалне заштите читавог становништва у случају болести, инвалидности, старости, смрти и незапослености. Чак, још уже везује се само за остварење сигурних материјалних услова живота и рада, или пак само за она стања која се обично називају социјалним ризицима. У ширем смислу подразумева целовит, повезан систем друштвених мера који гарантује одговарајући стандард живота и благостања људи, чији је саставни део и подручје социјалног осигурања, тј. уже схватање социјалне сигурности. У том смислу Душан Лакићевић социјалну сигурност одрећује као „скуп друштвених акција и мера ради гарантовања животних услова људи поводом социјалних ризика, као што су: материнство, болест, инвалидност, незапосленост, старост и сл.“(Lakićević, 1991).

У том смислу схваћене основне сфере социјалне сигурности: заштита здравља, запосленост и зарада који обезбеђују бар минимум егзистенције, заштита на раду, право на образовање, право на стан и минималне услове становања, осигурање за случај болести, материнства, инвалидности, старости, незапослености, смрти храниоца и социјална заштита породице, деце, остарелих, инвалидних, материјално необезбеђених и за рад неспособних лица. У ужем смислу по овом аутору социјална сигурност обухвата социјално осигурање које у савременим условима има тенденцију да прерасте у социјално обезбеђење становништва једне земље.

Милосав Милосављевић социјалну сигурност схвата као систем осмишљених и организованих економских, социјалних, идеолошких, политичких, правно-институционализованих и других мера и активности којима се обезбеђују стабилни и повољни услови живота и рада појединаца, породица и других друштвених група; могућности напредовања у животу и раду и предупређење различитих узрока и услова човекове отуђености и експлоатације, осујећености и угрожености. Она обухвата стабилност друштвеног положаја, материјалних и културних услова живота, могућности продукције и репродукције живота; услове оспособљавања за обављање радних и других друштвених улога; стабилност радних услова и радног положаја, подразумевајући и могућности напредовања у раду; услове и могућности развоја и испољавања стваралачких способности и суштине човека, укључујући и спречавање услова који води ризику погоршања или смањења могућности и услова рада (Милосављевић, 2013). 
Појам социјалне безбедности треба разликовати и од појма социјалне заштите. Не постоји сагласност о одређивању појма социјалне заштите и могу се разликовати пет гледишта:

- прво, социјалну заштиту посматра као специфичну државну, односно друштвену делатност која се бави задовољавањем основних животних потреба појединаца и друштвених група које су стално или повремено без своје кривице у немогућности да сами обезбеде услове за живот и напредовање у животу;

- друго, социјалну заштиту своди на социјално старање;

- треће, социјалну заштиту схвата као систем мера путем којих друштвена заједница обезбеђује и пружа одговарајуће облике заштите и помоћи грађанима/појединцу, породици или групи када се нађу у положају да без те помоћи не могу да ублаже или отклоне неповољну ситуацију у којој су се нашли;

- четврто гледиште истиче обавезу друштвене заједнице да преко социјално-заштитне функције, са позиција солидарности и хуманизма, штити своје чланове и пружа материјалну и друштвену помоћ, да их стимулише и оспособљава да предупређују и савлађују тешкоће;

и

- пето, социјалну заштиту одређује као интегрални део социјалне политике (Vuković, 2005).

Социјална заштита може да се одреди као вид социјалне политике преко које се спречавају узроци и отклањају последице оних друштвених ситуација појединаца, породица и друштвених група које имају обележја социјалне угрожености, постоје озбиљне сметње у социјалном, физичком и психичком развоју појединаца, у функцијама, односима и структури породице и јављају се социјални проблеми. Основни принципи социјалне заштите су: хуманизам, солидарност $u$ узајамност.

Хуманизам значи начинити човечним, уљуђивати, дати облик и природу какви људима доликују, почовечити. У друштвеним наукама појам се везује за све што је људско у позитивном смислу, што повољно утиче на развијање и поштовање људских особина. Појам се везује и за етички став који полази од потребе да сви друштвени односи треба да буду засновани на уважавању људске природе као највише вредности у друштву. Солидарност подразумева међузависност и повезаност људи, која намеће колективне ставове, вредности и одговарајуће облике сарадње. Узајамност је у вези са солидарношћу и односима међу људима и подразумева реципроцитет у правима и дужностима. Солидарност и узајамност се заснивају на међусобним интересима и међусобној повезаности (Vuković, 2005).

Социјално обезбеђење такође треба разликовати од социјалне безбедности, али и од социјалне сигурности и социјалне заштите. Схвата се на више начина:

- прво, као развијен систем социјалног осигурања преко кога се у случајевима социјалних ризика и стања социјалне потребе обезбеђује социјална сигурност читавог становништва;

- друго, као скуп мера државе и других институција у друштву 
са тежњом да се обезбеди минимални услови живота за све грађане без обзира на то да ли раде или не и

- треће, као систем социјално-политичких мера у циљу

гарантовања одређених извора сигурности у приходима, социјалном положају и помоћи за стања посебних животних тешкоћа (Vuković, 2005).

Социјално обезбеђење се може одредити као систем социјалних јавно-правних мера којима се гарантује и обезбеђује задовољавање основних потреба, чији је циљ остварење социјалне сигурности грађана у оним животним ситуацијама када они сами или уз помоћ своје породице нису у могућности да то учине, па им је зато потребна помоћ друштва.

\section{ИНДИКАТОРИ СОЦИЈАЛНЕ БЕЗБЕДНОСТИ}

У савременим условима при утврђивању индикатора ${ }^{3}$ социјалне безбедности треба имати у виду схватања квалитета живота, као и општеприхваћени модел развоја, одрживи развој. У том смислу полазећи од друштвених циљева развоја, индикатори социјалне безбедности треба да пружају податке о тренутном стању у области запослености, зарада, безбедности на раду, заштити здравља, образовању, становању, осигурању за случај болести, материнства, инвалидности, старости, незапослености, смрти храниоца и социјалној заштити породице, деце, остарелих, инвалидних, материјално необезбеђених и за рад неспособних лица, и од значаја су за креирање политике друштвеног развоја. Међутим, осим ових објективних показатеља из сфере остваривања основних људских права, мора се уважавати и субјективни осећај појединаца о степену социјалне безбедности. У том смислу чине се напори за дефинисањем индикатора који hе континуирано пратити степен остваривања социјалне безбедности.

Полазећи од добробити појединца и друштва, Ханс Херберт Нол (Noll) сматра да при одређивању индикатора социјалне безбедности треба поћи од савременог схватања квалитета живота, социјалне кохезије и одрживог развоја, при чему „квалитет живота треба да покрије димензије индивидуалног благостања“, а социјална кохезија и одрживост димензију „друштвеног или колективног благостања“. Индивидуално благостање обухвата квалитет живота, услове живота

\footnotetext{
3 Индикатори представљају скуп статистичких датости, одабраних и организованих тако да описују услове и тенденције неке појаве. Представљају посебно својство, карактеристику или особину система“" и представљају мерљиви део система. Омогућавају свеобухватну али истовремено и селективну процену. Селективност се огледа у томе што се од великог броја података, врши избор само оних који ће најрелевантније показати стање. (Према: Mario Bunge, What is a quality of life indicators. Social indicators research, Vol. 2, No. 1 (1975), p. 65 и Gilbert C. Gallopin, Indicators and their Use: Information for Decision-making. In: B. Moldan and S. Billharz (eds.), Sustainability Indicators: Report of the Projecton Indicators of Sustainable Development. Chichester and New York: John Wiley \& Sons, 1997).
} 
и субјективно благостање, а друштвено/колективно благостање социјалну кохезију (неједнакости, диспаритете, искљученост; друштвене односе, везе, укљученост (друштвени капитал) и одрживост (природни и друштвени капитал) (Noll, 2002).

Захваљујући његовом раду и Центру за истраживање социјалних показатеља ГЕСИС, Института за друштвене науке из Лајбница, израђен је Европски сет социјалних индикатора који се користи за континуирано праћење и анализу појединачне и друштвене добробити европских грађана у погледу квалитета живота, социјалне кохезије и одрживости, као и промене у друштвеној структури европских друштава. Систем индикатора покрива 13 области и 8 димензија (Табела 1) које се у свакој од области мере различитим индикаторима. ${ }^{4}$

\section{Табела 1}

Области и димензије социјалне безбедности

\begin{tabular}{|c|c|}
\hline Област & Димензија \\
\hline Становништво, домаћинстава и породице & \multirow{10}{*}{$\begin{array}{l}\text { објективни услови живота } \\
\text { субјективно благостање } \\
\text { разлике, неједнакости и } \\
\text { социјална искљученост } \\
\text { друштвени односи и везе } \\
\text { људски капитал } \\
\text { природни капитал } \\
\text { демографска и друштвено- } \\
\text { економска структуре } \\
\text { вредности и ставови }\end{array}$} \\
\hline $\begin{array}{l}\text { Приходи, животни стандард и ниво } \\
\text { потрошње }\end{array}$ & \\
\hline Тржишта рада и услови рада & \\
\hline $\begin{array}{l}\text { Образовање и стручно усавршавање } \\
\text { Здравље }\end{array}$ & \\
\hline Стамбени услови & \\
\hline Социјално сигурање & \\
\hline $\begin{array}{l}\text { Друштвена безбедност и криминал } \\
\text { Друштвено и политичко учешће и } \\
\text { интеграција }\end{array}$ & \\
\hline Мобилност и транспорт & \\
\hline $\begin{array}{l}\text { Жлооодно време, медији и култура } \\
\text { Животна средина }\end{array}$ & \\
\hline Укупни животни усл & \\
\hline
\end{tabular}

Европски систем социјалних индикатора узимајући у обзир индивидуалну и друштвену добробити омогућује избор једног или више индикатора за сваку од њих. За сада дато 650 индикатора за 9 од 13 области. У Табели 2 приказане су области и индикатори уз напомену да за све димензије нису одређени посебни индикатори.

\footnotetext{
4 Европски систем социјалних индикатора заснива се на изворима података који ће осигурати најбољи могући ниво упоредивости по земљама и времену. Извори података који се користе укључују међународне званичне статистике које обезбеђује ЕУРОСТАТ или ОЕЦД, као и микроподатаке из разних званичних извора, као и податке научно заснованих кроснационалних истраживања. (Исто).
} 
Табела 2

Области, димензије и индикатори Европског система социјалне безбедности

\begin{tabular}{|c|c|c|c|}
\hline Област & Димензија & $\begin{array}{l}\text { Мерљива } \\
\text { димензија }\end{array}$ & Индикатори \\
\hline $\begin{array}{l}\text { Приходи, } \\
\text { животни } \\
\text { стандард } \\
\text { и ниво } \\
\text { потрошње }\end{array}$ & $\begin{array}{l}\text { Субјективно } \\
\text { благостање }\end{array}$ & $\begin{array}{l}\text { Субјективна } \\
\text { процена } \\
\text { финансијске } \\
\text { ситуације } \\
\text { и нивоа } \\
\text { животног } \\
\text { стандарда }\end{array}$ & $\begin{array}{l}\text { Комфоран живот са садашњим } \\
\text { примањима } \\
\text { Потешкоће са садашњим } \\
\text { примањима } \\
\text { Способност да се састави крај } \\
\text { са крајем } \\
\text { Субјективно добра примања } \\
\text { Субјективно добар животни } \\
\text { стандард } \\
\text { Задовољство финансијском } \\
\text { ситуацијом } \\
\text { Субјективна оцена ризика од } \\
\text { сиромаштва }\end{array}$ \\
\hline \multirow[t]{3}{*}{ Здравље } & \multirow[t]{3}{*}{$\begin{array}{l}\text { Субјективна } \\
\text { процена стања }\end{array}$} & $\begin{array}{l}\text { Субјективна } \\
\text { процена } \\
\text { здравственог } \\
\text { стања }\end{array}$ & $\begin{array}{l}\text { Добро здравствено стање: } \\
\text { Целе полулације } \\
\text { Мушкараца } \\
\text { Жена } \\
\text { Популације старости 15-39 } \\
\text { година } \\
\text { Популације старости 40-59 } \\
\text { година } \\
\text { Популације старости 60-69 } \\
\text { година } \\
70 \text { и више година }\end{array}$ \\
\hline & & Субјективна & $\begin{array}{l}\text { Оцена здравствених услуга на } \\
\text { локалном нивоу }\end{array}$ \\
\hline & & $\begin{array}{l}\text { здравственог } \\
\text { система }\end{array}$ & $\begin{array}{l}\text { Оцена здравствених услуга на } \\
\text { државном нивоу }\end{array}$ \\
\hline \multirow{7}{*}{$\begin{array}{l}\text { Животна } \\
\text { средина }\end{array}$} & \multirow{7}{*}{$\begin{array}{l}\text { Субјективна } \\
\text { процена стања }\end{array}$} & \multirow{3}{*}{$\begin{array}{l}\text { Перцепција } \\
\text { животне } \\
\text { средине }\end{array}$} & $\begin{array}{l}\text { Забринутост због загађења } \\
\text { ваздуха }\end{array}$ \\
\hline & & & Забринутост због нивоа буке \\
\hline & & & $\begin{array}{l}\text { Забринутост због загађења } \\
\text { воде }\end{array}$ \\
\hline & & \multirow{4}{*}{$\begin{array}{l}\text { Задовољство } \\
\text { животном } \\
\text { средином }\end{array}$} & $\begin{array}{l}\text { Незадовољство стањем } \\
\text { животне средине } \\
\text { Незадовољство квалитетом } \\
\text { воде }\end{array}$ \\
\hline & & & Незадовољство нивоом буке \\
\hline & & & $\begin{array}{l}\text { Незадовољство квалитетом } \\
\text { ваздуха }\end{array}$ \\
\hline & & & $\begin{array}{l}\text { Незадовољство обимом } \\
\text { зелених површина }\end{array}$ \\
\hline
\end{tabular}

Извор: http://gesis-simon.de/simon_eusi/index.php\#

У Табели 2 дати су индикатори социјалне безбедности које је формирао Институт за социјалне науке из Лајбница (GESIS) и који су прихваћени на нивоу ЕУ. Треба напоменути да тебела приказује 
само оне индикаторе који су у потпуности или делимично обрађени у оквиру емпиријског дела доктората (http://gesis-simon.de/simon_eusi/ index.php\#).

Остваривање социјалне безбедности у тесној је вези с остваривањем људске безбедности и одрживим развојем.

Као области социјалне безбедности у оквиру истраживања људске безбедности се наводе: стабилност породице, становање, медији и комуникације, локална заједница, синдикати, културни идентитет и скуп вредности (Indikatori ljudske bezbednosti u Srbiji: izveštaj za 2004).

За сваку од наведених области конструисан је сет индикатора. Као показатељ стабилности породице, узима се насиље у породици, које се мери: распрострањеношћу насиља према типовима (психичко, физичко, сексуално), полном и старосном структуром насилника и жртава; нормативним оквиром заштите од насиља, имплементацијом позитивно правних прописа, стопом пријављивања полицији, бројем евидентираних случајева у центрима за социјални рад и НВО, учесталошћу обраћања жртва центрима и НВО сектору, постојањем техничких, материјалних, институционалних и стручних претпоставки за ефикасну и квалитетну превенцију и заштиту од насиља у породици (Indikatori ljudske bezbednosti u Srbiji: izveštaj za 2004).

\section{СОЦИЈАЛНА ПОЛИТИКА, СОЦИЈАЛНА БЕЗБЕДНОСТ И СОЦИЈАЛНА ЗАШТИТА У СРБИЈИ}

Социјална политика има за циљ да обезбеди услове за живот и напредовање у животу оним члановима друштвене заједнице, који без своје кривице, стално или привремено нису у могућности да сопственим средствима и својим радом сами себи остваре те услове, ${ }^{5}$ те су изложени ризицима сваке врсте, од немогућности задовољавања егзистенцијалних потреба до укључивања у друштвени и културни живот заједнице (Spicker, 2014).

Односно циљ јој је , да изједначи њихове могућности да побољшају свој и живот своје деце и да помогне онима који не могу сами да брину о себи“ да преусмери ресурсе ка угроженим категоријама становништва (Речник социјалне сигурности, 2006).

Део је глобалне политике једног друштва, те је битно опредељена владајућим вредносним системом, као и економским и политичким факторима датог друштва. С обзиром на глобалну кризу, чак и у најразвијенијим земљама, социјална политика добија све већи значај, а систем социјалне безбедности се примењујење на све већем броју људи и друштвених група (Čekerevac, 1999).

5 О социјалној политици видети више: Spicker, 2014; Pejanović, 2008; Kočović, 2007; Гавриловић, 2005; Wilensky, 1991; Stupar, 1960. 
Срж социјалне политике чине различити облици социјалне заштите, социјалног осигурања, социјалне помоћи, здравствене заштите и социјалне услуге. Активности социјалне заштите у Србији сежу у далеку прошлост. Током векова заснивале су се на народним обичајима, моралним нормама и неписаним правилима. Различити облици помоћи и сарадње у решавању различитих животних тешкоћа појединаца и група развијале су се под окриљем Православне цркве. Током средњег века верски објекти су коришћени као прва склоништа за сиромашне, инпровизоване здравствене институције и места за збрињавање различитих категорија угрожених лица. У XVIII и XIX веку држава постаје носилац социјално-заштитних функција. Разлог томе били су чести ратни сукоби, након којих је велики број инвалида и ратне сирочади захтевао одговарајуће облике заштите. Након Првог светског рата, изграђен је велики број домова за угрожену децу. Први пут се и међународне хуманитарне организације укључују у пружање помоћи угроженим лицима. Социјална заштита је постала монопол државе након Другог светског рата, јер је држава била одговорна за сваки људски проблем (http://www.prafak.ni.ac.rs/files/master-radovi/jovana-radovanovic. pdf).

Систем социјалне заштите какав данас постоји у Србији почео је да се развија средином XX века. Тада је почело оснивање центара за социјални рад и до краја шездесетих година прошлог века готово све општине у Србији имале су ове центре. 1957. године у Београду је основан Завод за социјална питања. То је била прва званична институција коју је основала држава. У истом периоду почело је и школовање социјалних радника, а упоредо су се развијале и установе за смештај корисника. Међутим, у задњим деценијама XX века, уништени су први знаци опоравка у овој области (Вуковић, 2002).

Данас, сиромаштво уз високу незапосленост представља један од највећих проблема. Заштита посебно угрожених особа регулисана је у оквиру Закона о социјалној заштити, чијим доношењем је престао да важи Закон о социјалној заштити и обезбеђивању социјалне сигурности грађана (Косановић, 2011).

Међутим, транзициони процеси, посебно у области еконмског реструктуирања намећу потребу укључивања шире друштвене заједнице како би се овим лицима обезбедили минимални услови за живот достојани човека и како би се омогућило да сви појединци и друштвене групе у потпуности учествују у економским, друштвеним и културним токовима.

Тешкоће и препреке са којима се суочавају особе у ризику од сиромаштва су кумулативне. Нови друштвени изазови везани за транзицију, глобализацију, демографске промене и општедруштвене трендове.

Систем социјалне безбедности у Србији делимично је пренет из периода СФР Југославије, где је постојао широк спектар 
социјалног и стамбеног обезбеђења. Састоји се из: 1. система социјалног осигурања, 2. система друштвене бриге о деци и 3. система друштвене заштите бораца, војних инвалида и цивилних инвалида рата и социјалне заштите.

Систем обавезног сочијалног осигурања обухвата: 1. пензијскоинвалидско осигурање, 2. здравствено осигурање и 3. осигурање за случај незапослености.

На овај начин су покривени сви ризици за случај старости, повреда, болести или незапослености и гарантује се социјална безбедност осигураника и њихових чланова породице.

Пензијско-инвалидско осигурање може бити обавезно и добровољно. Ово осигурање се базира на начелима узајамности и солидарности. Осигураницима се обезбјеђују права у случају старости и инвалидности, а у случају смрти осигураника односно корисника пензије право се обезбјеђује члановима њихових породица. По Закону о пензијском и инвалидском осигурању предвиђене су следеће врсте права: право на старосну пензију; право на инвалидску пензију; за случај смрти право на породичну пензију; право на новчану надокнаду за случај телесног оштећења проузрокованог повредом на раду или професионалном болешћу; право на новчану накнаду за помоћ и негу другог лица (Закон о пензијском и инвалидском осигурању 2014, бр. 75).

Здравствено осигурање подразумева право на здравствену заштиту које имају сви становници. Систем здравственог осигурања подразумева пружање медицинских услуга, које обухвата лекарске прегледе, медикаментно и болничко лечење, специјалистичке, стоматолошке, хирушке и друге интервенције, као и право на бесплатне лекове и лекове за које се сноси одређена партиципација. Право на здравствену заштиту имају сви становници, а право на обавезну и бесплатну здравствену заштиту имају: 1. деца до 15. године живота, ученици и студенти, а најкасније до 26. године живота, 2. жене у вези са планирањем породице (трудноћа, порођај), 3. лица старија од 65године живота, 4. хендикепирана и инвалидна лица, 5. незапослени и корисници социјалне помоћи и 6. друга лица у циљу сузбијања заразних болисти и других тешких болести. Здравствена заштита обухвата и новчану накнаду запосленим лицима, која су због болести спречена за рад и одређена је процентуално у зависности од врсте болести и дужине боловања. Обухвата и накнаду за време трудничког и породиљског одсуства, као и накнаду за одсуствовање с рада у циљу неговања болесног детета (Zakon o zdravstvenoj zaštiti, 2005, br. 107).

Незапослена лица остварују одређена права у вези са запошљавањем, која имају за крајњи циљ запошљавање таквог лица у складу са Законом о запошљавању и осигурању за случај незапослености (Закон о запошљавању и осигурању за случај незапослености, 2010, бр. 88). 
Поред осталих, остварују и право на слободан избор занимања и запослења, да се обавештавају код Националне службе и агенције о могућностима и условима за запошљавање и да бесплатно користе услуге Националне службе и агенције. Ова права се остварују код Националне службе за запошљавање (HC3) која је носилац осигурања по том основу у Републици Србији, и у агенцијама за запошљавање.

Поред наведених права, лице може обавезним осигурањем за случај незапослености, обезбедити следећа права: новчану накнаду; здравствено осигурање и пензијско и инвалидско осигурање и друга права у складу са законом. Средства за остваривање ових права обезбеђују се из доприноса за обавезно осигурање за случај незапослености.

Друштвена брига о деци подразумева помоћ породицама у остварењу репродуктивне, заштитне, васпитне и економске функције. Право на предшколско васпитање, образовање, одмор и рекреацију деце, културне, спортске и стваралачке активности деце, рад са децом без родитељског старања, рад са децом са сметњама у развоју, посебан новчани додатак за децу, а нарочито за треће дете, смештај деце без родитељског старања, смештај и васпитни рад са децом криминалног и деликвентног понашања, заштита и збрињавање деце код изложености деце насиљу и неприродним и тешким условима живота.

Систем друштвене заштите борача, војних инвалида и иивилних инвалида рата заснован је на закону о социјалној заштити. Овим законом уређују се услови за остваривање права бораца народноослободилачког рата, учесника ранијих ратова за ослобођење земље, чланова њихових породица, војних инвалида и корисника породичне инвалиднине (Закон о правима бораца, војних инвалида и чланова њихових породица, бр. 54/89).

Системи социјалне безбедности свих држављана установљена је Уставом Републике Србје који је донела и усвојила Влада Републике. Средства којима се спроводе социјална давања одвајају се из буџета Републике. Системе социјалне безбедности се спроводе преко министарстава, Министарства рада, запошљавања и социјалне политике и Министарства здравља. Належне установе, центри за социјални рад су задужене за директне контакте са социјално угроженом популацијом и осталим лицима, која могу остварити права из области социјалне заштите (Kosanović, Paunović, 2012).

Корисници социјалне заштите су потенцијално сви грађани, који под одређеним околностима, нису способна да задовољавају своје основне животне и егзистенцијалне потребе.

Република Србија погођена је дугогодишњом транзицијом, приватизацијом, економском кризом, услед којих је дошло до великог броја незапослених и зависних од социјалне помоћи. Такође, смањена су средства којима се финансирају социјалне потребе услед пада производње и стагнација у привредном развоју. Мада постоји 
развијен систем социјалне заштите и обезбеђења, средстава којим се подмирују потребе социјално угроженог становништва су веома мала, па су и накнаде у случају социјалног обезбеђења веома ниске и не подмирују основне потребе појединца и породице.

Социјална помоћ у новембру 2015. год. у Србији на месечном нивоу по особи износила је 7898,00 динара, што дневно износи 263,26 динара. Социјалну помоћ добијају особе које немају никакве друге приходе, а од ових симболичних средстава треба да задовоље све егзистенцијалне потребе: храна, средства за хигијену, одећа, обућа, измирење комуналних трошкова. Породице које остварују право на додатак за децу, добијају од 2659,11 дин. до 3456,86 дин. по детету на месечном нивоу, па се може рећи да је улога државе у стимулисању наталитета симболична (http://www.minrzs.gov.rs/lat/visine-socijalnihdavanja).

У Републици Србији око 650.000 становника је сиромашно, око 100.000 становника живи испод доње линије сиромаштва. За 32000 социјално угрожених корисника, постоје 72 народне кухиње, које сиромашнима обезбеђују један оброк дневно, што је далеко од европских стандарда (http://www.minrzs.gov.rs/lat/visine-socijalnih-davanja).

\section{УМЕСТО ЗАКЉУЧКА}

Суочене са растом неједнакости, земље Централне и Источне Европе бележе значајан раст сиромаштва у првим годинама транзиције, што представља озбиљну препреку у спровођењу реформи. У сваком случају, неједнакост у расподели дохотка и сиромаштво су саставни део транзиције, при чему растућа неједнакост утиче на раст сиромаштва. Нагли раст сиромаштва у земљама у транзицији последица je, пре свега, економске транзиције: пада аутпута и просечног дохотка домаћинства и раста неједнакости у расподели дохотка. Што све заједно има има негативан утицај на социјалну безбедност становника.

Неспорно је да је пад аутпута битан чинилац раста сиромаштва у овом региону. По Милановићу (1998) раст неједнакости у земљама у транзицији резултат је:

1) трансфера рада из државног сектора, са релативно мање неједнакости, у приватни сектор, који карактерише већи степен неједнакости,

2) раста концентрационог коефицијента надница (последица раста неједнакости међу примаоцима дохотка) у приватном и државном сектору,

3) најважнији извор раста неједнакости јесу растуће разлике међу групама, што је последица промена у саставу запослености.

У Извештају о светском развоју (World Development Report) из 1996, године дата је процена сиромаштва у земљама у транзицији (World Development Report, p. 70 and 71). Ова процена базирана је на заједничкој линији сиромаштва за земље Централне и Источне Европе, укључујући земље бившег СССР. Сиромаштво је значајно порасло у 
балканским земљама, а посебно у земљама бившег СССР. Ниво сиромаштва се стабилизовао у земљама које су изашле из кризе и интензивирале привредни раст.

Према Извештају Светске банке у периоду 1998-2003 у Централној и Југоисточној Европи и земљама бившег СССР-а око 40 милиона људи ослободило се сиромаштва. У 1998. години 20\% становништва овог региона живело је у сиромаштву, а 2003. године $12 \%$. У том смислу, Шигео Kamcy, потпреседник Светске банке за Европу и Централну Азију, указује на значај привредног раста за побољшање услова живота. „Да би они били одрживи (услови живота - прим. аутора) потребно је више радних места, за оне који их немају, поготову у сеоским подручјима и у неким мањим градовима у Региону“ (World Development Report, p. 70 i 71). Сиромаштво је најизраженије у земљама са средњим просечним дохотком (Казахстан, Пољска, Русија и Украјина). Према овом Извештају, већина сиромашних ради, а најугроженије групе су: млади, становници села и мањих градова, незапослени, недовољно образоване особе и особе које припадају запостављеним мањинама, као што су Роми (www.worldbank.org). Указује се и на чињеницу да су транзициони процеси довели до померања расподеле прихода, али на различите начине. Рецимо, у Русији и Казахстану дошло је до пораста производње, а расподела прихода је ишла према сиромашнима. Насупрот томе, без обзира на повећану производњу, расподела прихода у Пољској није ишла ка сиромашнима, те је дошло до повећања сиромаштва, и то пре свега у градовима. Међутим, како се констатује у овом периоду није повећан број радних места, па у земљама чланицама ЕУ и земљама Југоисточне Европе стопа незапослености износи $44 \%$, што је у супротности са тзв. Лисабонским циљем, а уједно оставља могућности за повећање стопе сиромаштва. „У извештају се упозорава да ће, уколико се тенденција раста незапослености настави, мање људи бити избављено из сиромаштва. Ако растуће неједнакости у квалитету основних услуга не крену у супротном смеру, оне ће ослабити благовремене ефекте раста" (www.worldbank.org).

Аутори Извештаја се залажу за поспешивање раста и прерасподелу дохотка у корист сиромашних и у том смислу предлажу: $n p в о$, peформе у сектору предузетништва; друго, политику која ће промовисати раст пољопривреде и села уз њену интеграцију у остатак привреде, у односу на тржиште рада и капитала, приступ кредитима, трговини и услугама; mpeће, стварање већих могућности за развој у заосталим регионима; четврто, побољшање квалитета основних услуга и могућности приступа услугама за сиромашне и пето, унапређење друштвене мреже социјалне сигурности (www.worldbank.org).

Треба свакако имати у виду да драстичне промене које су наступиле са променама у овом периоду носе стрес и несигурност. У многим земљама у транзицији несигурност живота након краха централистичког планирања повезано је са читавим низом болести. Ту је растући стрес у породици као последица пада дохотка и раста цена хране. Затим, раст развода, смањење броја порођаја, раст алкохолизма и нар- 
команије, нарушавање здравља (лоше здравље је само по себи извор стреса у породици) и сл. Криминал и корупција су порасли, што је утицало на даље смањење сигурности становништва. На крају, ту је и стрес везан за прилагођавање новој култури (www.worldbank.org).

Емпиријска истраживања потврђују да „процеси названи транзицијом“ теку у знаку појачаног разочарања извршеним променама и порастом скептицизма када је реч о будућности постсоцијалистичких друштава. Такође показују да је унутар распрострањеног незадовољства тим променама садржана и свест да су многе од њих, посебно приватизација, супротстављене неким од основних људских вредности, пре свега социјалној праведности и поштењу (Видојевић, 2008).

У најуспешнијим земљама транзиције Централне и Источне Европе, након више година протеклих од пада берлинског зида, политичког и укупног стратешког опредељења за успостављање либералнодемократског поретка и евроатлантских интеграција, видљиви су знаци социјалног незадовољства резултатима транзиције, а социјални бунт и политички конфликти су у значајној мери обележени питањима етничког и културног идентитета, идеолошким расколима и њима обележеном историјском прошлошћу. „Све чешће се говори о „post-accession crisis”, односно о различитим манифестацијама било политичке нестабилности или економске кризе и социјалног незадовољства маса у државама бившег „реал-социјализма“, које су најуспешније спровеле економску и политичку транзицију и већ постале чланице ЕУ и НАТО“ (Вујадиновић, 2007).

Приликом тумачења стања у земљама транзиције, мора се водити рачуна о томе да се не направи поравнавање различитих нивоа и узрока незадовољства грађана постсоцијалистичких земаља стањем у њиховим друштвима. Не могу бити исти нивои незадовољства у Словенији, која је (према подацима статистичког уреда те државе) у 2007, имала 16.616 евра бруто друштвеног производа по становнику, у 2013. години 19.096 евра (http://www.makroekonomija.org), и у земљама међу које спада и Србија, где је тај доходак вишеструко мањи. То важи и за упоређивање стања запослености, сиромаштва, социјалне заштите, доступности високог образовања деци и омладини из сиромашних породица, као и у другим областима друштвеног живота важним за егзистенцијални положај сваког појединца. Раширено незадовољство грађана, као општа одлика стања „духа““ изразите већине грађана у тим земљама, произлази највише из осећаја преваре услед бескрупулозног стицања богатства, веома оштрих социјалних неједнакости, нових облика приватизације власти, сада од вишепаријских олигархија и њиховог повезивања с криминализованим богаташима, што поново доводи до непремостивог јаза између владајућих и оних над којима се влада, опадања морала и сличних појава (Лаш, 1996). Оваква драматична економска ситуација у земљама транзиције знатно утииче на смањење степена социјалне безбедности становништва овог региона.

Стопа незапослености у Србији је 2014. године опала за 3,2 процентна поена и на крају прошле године је износила 16,8\%, наводи РЗС (Републички завод за статистику). Анкетна стопа запослености 
за четврти квартал 2014. године била је 50,4\% (за становништво од 15 до 64 године), а број запослених 2.322.201 лице. Према подацима РЗС, раст запослености 2014. године довео је до повећања броја запослених за 53.451 лице у односу на октобар 2013. године. Према истом извору, стопа ризика од сиромаштва у 2014. години износила је $25,6 \%$.

Према подацима из Анкете о дохотку и условима живота из 2014. године (Statistics on Income and Living Conditions - SILC) 42,1\% или око три милиона људи из Србије изложено је ризику сиромаштва или социјалној искључености. Та вредност је знатно већа од вредности просека 28 земаља ЕУ (24,3\%) и просека нових 12 земаља чланица без Хрватске (30,7\%). После Бугарске и Румуније, та вредност је већа него у било којој другој земљи ЕУ. Према наведеном извору, чак 65,1\% становништва суочено је са одређеним фактором ризика, будући да је рад и интензитет рада чланова домаћинства основни предуслов вишег дохотка и бољег животног стандарда (http://ec.europa.eu).

Стопа ризика од сиромаштва је проценат лица које имају расположиви доходак испод прага ризика од сиромаштва. У Србији је за 2014. годину, према подацима РЗС, релативна линија ризика од сиромаштва била 13408 РСД (http://webrzs.stat.gov.rs). Ако се говори о лицима у домаћинствима у којима чланови не раде или раде веома ретко, и која имају релативно низак доходак, 8,9\% становништва је сиромашно и живи у домаћинствима са веома ниским радним интензитетом. У Табела 3 приказано је кретање стопе сирмаштва у Србији.

Табела 3

Проценат сиромашних у Србији по годинама

\begin{tabular}{|l|c|c|c|c|c|}
\hline година & 2008 & 2010 & 2012 & 2014 & 2016 \\
\hline$\%$ & 6,1 & 9,2 & 8,8 & 8,9 & 7,2 \\
\hline
\end{tabular}

Извор: Сиромаштво у Србији у 2014 години, август 2015. (Наведено према: Мијатовић, Сиромаштво у Србији, 2008-2014, Табела 14).

Структура сиромаштва показује да су највише погођене рањиве категорије: деца, млади и ниже образовани који су више изложени ризику од сиромаштва. Стопе сиромаштва деце у Србији знатно су изнад просечних стопа за општу популацију, и много веће него у другим европским земљама. Утврђено је да високе стопе сиромаштва међу децом у Србији нису само последица ниске потрошње за дечје додатке и новчану социјалну помоћ, него и последица карактеристика социјалних накнада. Раније студије садрже неколико решења, али пројекат ФРЕН-а „Смањење сиромаштва деце у Србији: балансирање између унапређених социјалних накнада и политика које промовишу запослење родитеља“ (http://www.fren.org.rs), први оцењује утицај одређених реформских решења на стопу сиромаштва деце као и државни буџет.

Иако је стопа ризика сиромаштва деце у Србији знатно већа него у 28 земаља чланица ЕУ аналитичари наводе да је релативан поло- 
жај деце у односу на просек популације у Србији приближно исти као у 28 земаља чланица ЕУ. Забрињавајући је податак да се од укупног броја сиромашних у Србији, чак 50,7\% односи на лица старости од 25-65 година, док је проценат сиромашних старости до 13 година 17,4\%. (Šunderić, 2015) Према подацима РЗС из октобра 2013. стопа незапослености младих (15-24) износи 50\%, док једна четвртина младих спада у категорију који нису запослени, не школују се нити се усавршавају (NEET - not in employment, education or training). Према подацима РЗС за 4 квартал 2014. одине, учешће младих до 30 година у регистрованој незапослености износи $25,8 \%$. Такође, стопа ризика сиромаштва у Србији, као и у 28 земаља чланица ЕУ већа је код жена него код мушкараца.

Имајући у виду кретање стопе сиромаштва у Србији, у компарацији са другим земљама у региону и ЕУ, у октобру 2014. године Влада Србије усвојила је Други национални извештај о социјалном укључивању и смањењу сиромаштва у Републици Србији за период 2011-2014. године. Извештај обухвата: преглед законског, стратешког и институционалног оквира релевантних за процесе социјалног укључивања и смањења сиромаштва, анализу тренутног стања у релевантним областима, преглед реализованих мера, закључке и изазове и основне правце развоја за наредни период. Тим за социјално укључивање и смањење сиромаштва Владе Србије активно учествује у промовисању предузетничке културе, развијању различитих модела укључивања осетљивих група у економске активности, промоцији и развијању концепта социјалног предузетништва и активном укључивању на тржиште рада. Национални акциони плана запошљавања за 2016. годину дефинише мере у овој области.

\section{ЛИТЕРАТУРА}

Bohem, W. W. ,The Nature of Social Work“. Social Work 3, 2 (1958): 10-18. Bilanović, A. „Pregled dominantnih stanovišta o odnosu socijalne sigurnosti i ekonomskog razvoja“. U Istraživanja u oblasti socijalnog rada, socijalne zaštite i socijalne politike, priredili Z. Kuburić, M. Zotović, M. Škorić i A. Kišjuhas. Novi Sad: Filozofski fakultet, 2015.

Bunge, M. „What is a Quality of Life Indicators?“. Social Indicators Research 2, 1 (1975): 65.

Вуковић, Д. Системи соичјалне сигурности. Београд: Службени гласник, 2002.

Vuković, D. i A. Čekerevac. Socijalna politika i socijalne reforme. Beograd: Fakultet političkih nauka, Čigoja, 2007.

Vuković, D. Socijalna sigurnost i socijalna prava. Beograd: Čigoja štampa, 2005.

Wilensky, H. L. „,The Nation-state, Social Policy, and Economic Performance“. In Globalizzazione e sistemi di welfare, ed. M. Ferrara. Torino: Edizioni della Fondazione G. Agnelli, 1991. 
Gallopin, G. C. „Indicators and their Use: Information for Decisionmaking“. In Sustainability Indicators: Report of the Projecton Indicators of Sustainable Development, edited by B. Moldan and S. Billharz. Chichester and New York: John Wiley \& Sons, 1997.

Гавриловић, А. Социјална политика. Бања Лука: Филозофски факултет, 2005.

Indikatori ljudske bezbednosti u Srbiji: izveštaj za 2004. Beograd: Fakultet civilne odbrane Univerziteta u Beogradu, 2004.

Закон о социјалној заштити. Београд: „Службени гласник РС“, бр. 24/2011.

Закон о пензијском и инвалидском осигурању. Београд: „Службени гласник РC“, бр. 75/2014.

Zakon o zdravstvenoj zaštiti. Beograd: "Sl. glasnik RS”, br. 107/2005, 72/2009 - dr. zakon, 88/2010, 99/2010, 57/2011, 119/2012, 45/2013 - dr. zakon, 93/2014, 96/2015 i 106/2015.

Закон о запошљавању и осигурању за случај незапослености. Београд: «Службени гласник РС», бр. 36/2009 и 88/2010.

Закон о правима бораца, војних инвалида и чланова њихових породица. Београд: «Службени гласник РС», бр. 54/89 и 137/04.

Kočović, D. Socijalna politika. Beograd: Fakultet političkih nauka, 2007.

Косановић, Р. Соичјално право. Београд: Friedrich Ebert Stiftung, 2011.

Lakićević, D. Socijalna politika. Beograd: Savremena administracija, 1991.

Милосављевић, М. Социјална истраживања. Београд: Фондација „Солидарност Србије“, 2013.

Mihailo S., S. Socijalna politika. Beograd: Savremena administracija, 1968.

Milanovic, B. Income, Inequality, and Poverty during the Transition from Planned to Market Economy. Washington, D.C., World Bank, 1998.

Noll, Heinz-Herbert. "Towards a European System of Social Indicators: Theoretical Framework and System Architecture". Social Indicators Research 58, 1 (2002): 47-87.

Pejanović, S. Socijalna politika. Beograd: Fakultet za specijalnu edukaciju i rehabilitaciju, 2008.

Речник соиијалне сигурности. Београд: Council of Europe, децембар, 2006.

Резолуција ОУН, бр. 2200 A(XXI) од 16. 12. 1966.

Социологическая энцилопедия. Москва: Мысль, 2003, 83.

Симић, Д. Наука о безбедности - савремени приступи безбедности. Београд: Службени лист СРЈ и Факултет политичких наука, 2002.

Spicker, P. Social Policy - Theory and Practice. University of Bristol: Policy Press, 2014.

Стратегија националне безбедности Републике Србије. Београд, 2009. године. 
Stupar, M. Socijalna politika. Beograd: Savremena administracija, 1960.

Универзална декларацији о правима човека, 1948.

Čekerevac, A. Uporedna i međunarodna socijalna politika. Beograd: Savez društava socijalnih radnika Republike Srbije, 1999.

\section{Интернет извори}

http://www.unmikonline.org/regulations/unmikgazette/04serbian/SChri/ SCUniversal_Declaration_of_Human_Rights.pdf (приступљено: 10. 11. 2014).

http://www.ilo.org/global/lang--en/index.htm (Приступљено: 15. 11. 2014). http://www.kombeg.org.rs (приступљено: 10. 11. 2014).

http://www.coe.int/t/dg3/sscssr\%5CSource\%5CGlossSERBcyrillic.pdf (приступљено: 10. 04. 2016).

http://gesis-simon.de/simon_eusi/index.php\# (Приступљено: 14. 05. 2016). http://www.prafak.ni.ac.rs/files/master-radovi/jovana-radovanovic.pdf (приступљено. 22.02.2015).

http:/www.coe.int/sisp (приступљено: 12. 5. 2016).

\section{SOCIAL SECURITY AND ITS IMPLICATIONS IN SERBIA}

\section{Summary}

The need for safety and security is one of the primary human needs in addition to physiological ones. The evolution of human need for security can be traced back to the earliest human communities. It is clear that security as a human need has changed through history. The initial concept of security was related to the absence of physical threats and the sense of security in terms of physical integrity. Later on, as society developed, security as a human need extended its reach not only to physical security but also to the prohibition of discrimination, i.e. to the respect of equality, social justice, and human rights.

In contemporary science there are several different definitions and language combinations in the interpretation of social security. The concept of social security is the focus of many social sciences. Over the last few decades, both the West and the East have been developing social security studies within a substantially broader scope, which often involves almost all areas of social sciences.

This paper discusses the concepts of territorial and social security and their interdependence and relationship in the political and economic context of Serbia.

Key words: security, territorial security, social security, Serbia. 